\title{
Role of Different Concentration of PGRS (Plant Growth Regulators) On In Vitro Multiplication of Dendrobium fimbriatum Var.Oculatum Using Nodal Segments
}

\author{
Purnima Saikia ${ }^{1}$ and P.K.Borua ${ }^{2}$ \\ ${ }^{1}$ Monahari Devi Kanoi Girls', College, Dibrugarh-786001, Assam, India. \\ ${ }^{2}$ Department of Life Sciences', Dibrugarh University-786004,Assam, India.
}

\begin{abstract}
Dendrobium fimbriatum var.oculatum is an epiphytic orchid of of immense floricultural apppeal as well as some local medicinal values. It is a native to north-eastern India and parts of Indo-Chinese peninsula with a height of about $1 \mathrm{~m}$ bearing beautiful bunches of bright yellow flowers having a reddish brown blotch in the middle and reddish streaks at the base, mildly scented and flowers lasting for 8-10 days. Like many other orchids of this region, this species is also found to be in the verge of extinction, due to large-scale denundation of forest areas. So in order to preserve it from possible extinction, attempts are made to multiply it through in vitro culture of nodular portions. NAA $(1 \mathrm{mg} / \mathrm{l})$ in $\mathrm{MS}$ medium was found to be most effective for early initiation of bud and multiple shoot induction.Full strength liquid MS medium proved to be the best for nodal explant culture.
\end{abstract}

Key Words: in vitro technique, D.fimbriatum, nodular portions, NAA,IAA,BAP,KN,MS medium, liquid MS medium.

\section{Introduction}

Orchids are one of the most beautiful flowers in nature and Orchidaceae is the second largest family in India(Satish Kumar and Maninlal,1994).The North-East region is perhaps the richest orchid wealth in the world and about 800 species are known to occur in this region(Chadha, 1994). 350 species have been reported from Assam(Arora and Mukherjee,1983). Commercially, the orchid Dendrobium command a high demand in their price for extremely beautiful, intricately fabricated, highly colourful and long lasting flowers and have contributed immensely to the developement of international trade in floriculture (Lawler,1984). Dendrobium fimbriatum var.oculatum is a hard cane-type epiphytic orchid reaching a height of about $1 \mathrm{~m}$ producing beautiful bunches of bright yellow flowers with orbicular fimbriate lip having a large dark reddish -brown blotch in the middle and reddish streaks at base, mildly scented and flowers remaining fresh for 8-10days. The above orchid also has some local medicinal values like for the treatment of lethargy, madness, loss of appetite, lung cancer, stomache cancer, epilepsy, etc(Quattocchu,2012). Like many other orchids of this region, Dendrobium fimbriatum var.oculatum is also at the verge of extinction due to large-scale denundation of forest areas. The seeds are very few in number, so in order to conserve this beautiful orchid from further extinction, nodular portions were cultured aseptically in MS(Murashige and Skoog) medium (1962)using in vitro technique for early initiation of bud and multiple shoot induction. In vitro techniques provide better understanding of different physico-chemical requirements that might affect growth (Adritti et.al,1981).

\section{Materials And Methods}

Fresh and healthy nodular potions were collected from the Orchidarium of Dept. of Life Sciences, Dibrugarh University for the present study. The nodular portions so collected were first washed thoroughly, carefully under tap water, then with sterile DDW solution using 15\% Teepol. The nodular portions were surface sterilized by immersing in $0.01 \% \mathrm{Hgcl}_{2}$ solution for 2-3 minutes inside a laminar air flow cabinet. Again washed 2-3 times in sterile DDW. The nodular portions were then innoculated into the flasks containing MS medium(1962) with different concentrations of auxins(IAA,NAA) and cytokinins(BAP.KN). The plant growth regulators (PGRs) were taken as $1 \mathrm{mg} / 10 \mathrm{ml}$ of DW made up with $1000 \mathrm{ml}$ of MS medium. The explants were inoculated in different concentrations of IAA $(3,2,1 \mathrm{mg} / \mathrm{l}), \mathrm{NAA}(1,2,3 \mathrm{mg} / \mathrm{l}), \mathrm{BAP}, \mathrm{KN}$ and full, $1,2,1,4$ and 1/8 strength liquid MS medium. The percentage of sucrose is taken as $30 \mathrm{mg} / \mathrm{lt}$, agar $8 \mathrm{mg} / \mathrm{lt}$, $\mathrm{pH}$ of the medium adjusted to 5.6 before sterilization and autoclaved at $15 \mathrm{lbs} /(\mathrm{inch})$ for $10-15$ minutes. The inoculated flasks were stored on racks in growth room under continuous conditions of temperature $\left(22-24^{\circ \mathrm{c}}\right)$, humidity $(65 \%-70 \%)$ and 12hr/day light(2000-3500 lux).

The flasks were observed at regular intervals for the development and growth of buds, multiple shoot induction, roots, leaves etc.They were repeatedly sub-cultured at regular intervals and photographed whenever necessary. 


\section{Results and Discussion}

MS medium supplemented with NAA $1 \mathrm{mg} / \mathrm{lt}$ was found to be the most suitable for nodular explant culture in comparison to other auxins(IAA) and cytokinins(BAP,KN). Nodular segments in MS when supplemented with 1mg/lt NAA, the number as well the time taken for the growth and development of bud, leaves ,roots, multiple shoot induction ,plantlet height were faster and better than at higher concentrations of $\mathrm{NAA}(2 \mathrm{mg} / \mathrm{lt}, 3 \mathrm{mg} / \mathrm{lt})$.

Protuberance of first leaf and shoot was seen in 1NAA mg/lt and $2 \mathrm{mg} / \mathrm{lt}$ within 3-4 days and 6-7 days respectively, induction of a single shoot was seen in 1NAA mg/lt and 2mg/lt in within 14-15 days and 1617days of MS medium respectively(Table:1 and Table:2). Thus 1NAA mg/lt was selected for further subculturing of the above species. No favourable results were found from cytokinins.

Table 1: Response of various plant growth regulator(s) on the nodular portions of Dendrobuim fimbriatum var. oculatum in MS medium

\begin{tabular}{|c|c|c|c|c|}
\hline $\begin{array}{l}\text { Sl. } \\
\text { No. }\end{array}$ & $\begin{array}{l}\text { MS medium + PGR(s) } \\
(\mathrm{mg} / \mathrm{l})\end{array}$ & $\begin{array}{l}\text { First bud formation within } \\
\text { (days) }\end{array}$ & $\begin{array}{l}\text { First leaf formation within } \\
\text { (wks) }\end{array}$ & $\begin{array}{l}\text { First foot formation within } \\
\text { (wks) }\end{array}$ \\
\hline 1 & 3 IAA & $\begin{array}{l}23.33 \mathrm{c} \\
+1.70\end{array}$ & $\begin{array}{r}7.67 \mathrm{~d} \\
+0.471\end{array}$ & $\begin{array}{r}8.67 \mathrm{~d} \\
+0.471\end{array}$ \\
\hline 2 & $1 \mathrm{NAA}$ & $\begin{array}{r}14.67 \mathrm{c} \\
+0.471 \\
\end{array}$ & $\begin{array}{r}3.33 \mathrm{a} \\
+0.471 \\
\end{array}$ & $\begin{array}{r}6.33 \mathrm{a} \\
+0.471 \\
\end{array}$ \\
\hline 3 & $3 \mathrm{NAA}$ & $\begin{array}{l}16.33 \mathrm{~b} \\
+0.471 \\
\end{array}$ & $\begin{array}{l}4 \mathrm{~b} \\
+0.816\end{array}$ & $\begin{array}{r}6.67 \mathrm{a} \\
+0.471 \\
\end{array}$ \\
\hline 4 & 3 NAA & $\begin{array}{l}22.67 \mathrm{c} \\
\pm 0.471 \\
\end{array}$ & $\begin{array}{r}5.67 \mathrm{c} \\
+0.471 \\
\end{array}$ & $\begin{array}{r}7.67 \mathrm{~b} \\
+0.471 \\
\end{array}$ \\
\hline & $5 \%$ & 0.92132 & 0.38933 & 0.60315 \\
\hline
\end{tabular}

Means followed by common letter(s) are not significantly $(\mathrm{p}<0.05)$ different as determined by Duncan's New Multiple Range Test (DMRT).

IAA was slightly effective in promoting bud growth in Dendrobium fimbriatum var. oculatum. The same effect of the hormones was reported in Vanda (Rao and Avadhani,1963) and Spathoglottsis plicata (Chennaaveeriah and Patil,1975).(Table:1 and Table:2)

Table 2: Effect of different concentrations of plant growth regulator(s) and their response to the different parameters upon nodal explants of D. fimbriatum var. oculatum (3 months/ 12 weeks) in MS medium

\begin{tabular}{|c|c|c|c|c|c|c|c|}
\hline $\begin{array}{l}\text { Sl. } \\
\text { No. }\end{array}$ & $\begin{array}{l}\text { MS medium + } \\
\text { PGR }(\mathrm{s})(\mathrm{mg} / \mathrm{l})\end{array}$ & $\begin{array}{ll}\begin{array}{l}\text { Leaf length } \\
(\mathrm{cm})\end{array} & \\
\end{array}$ & $\begin{array}{l}\text { Root length } \\
(\mathrm{cm})\end{array}$ & $\begin{array}{l}\text { No. of leaves } \\
\text { per plantlet }\end{array}$ & $\begin{array}{l}\text { No. of roots } \\
\text { per plantlet }\end{array}$ & $\begin{array}{l}\text { Plantlet } \\
\text { height }(\mathrm{cm})\end{array}$ & $\begin{array}{l}\text { No. of multiple } \\
\text { shoot per plantlet }\end{array}$ \\
\hline 1 & 3 IAA & $\begin{array}{c}0.7 \mathrm{a} \\
+0.082 \\
\end{array}$ & $\begin{array}{r}0.57 \mathrm{a} \\
+0.047 \\
\end{array}$ & $\begin{array}{c}4 \mathrm{a} \\
+0.816 \\
\end{array}$ & $\begin{array}{r}2.33 \mathrm{a} \\
+0.471 \\
\end{array}$ & $\begin{array}{c}1.4 \mathrm{a} \\
+0.082 \\
\end{array}$ & $\begin{array}{c}1.0 \mathrm{a} \\
+0.816 \\
\end{array}$ \\
\hline 2 & $1 \mathrm{NAA}$ & $\begin{array}{r}1.23 \mathrm{a} \\
+0.125 \\
\end{array}$ & $\begin{array}{r}2.3 \mathrm{~b} \\
+0.163 \\
\end{array}$ & $\begin{array}{r}7.3 \mathrm{~b} \\
+0.471 \\
\end{array}$ & $\begin{array}{r}4.3 \mathrm{~b} \\
+0.471 \\
\end{array}$ & $\begin{array}{r}2.83 \mathrm{~b} \\
+0.125 \\
\end{array}$ & $\begin{array}{c}3.0 \mathrm{a} \\
+0.816 \\
\end{array}$ \\
\hline 3 & 2 NAA & $\begin{array}{r}1.03 \mathrm{~b} \\
+0.125 \\
\end{array}$ & $\begin{array}{r}2.17 \mathrm{~b} \\
\pm 0.094 \\
\end{array}$ & $\begin{array}{c}3.3 \mathrm{a} \\
+0.471 \\
\end{array}$ & $\begin{array}{r}4.3 \mathrm{~b} \\
+0.471 \\
\end{array}$ & $\begin{array}{r}2.47 \mathrm{~b} \\
+0.125 \\
\end{array}$ & $\begin{array}{c}2.0 \mathrm{a} \\
\pm 0.816 \\
\end{array}$ \\
\hline & $5 \%$ & 0.30265 & 0.23926 & 2.00183 & 1.311050 & 0.37067 & 2.07208 \\
\hline
\end{tabular}

Means followed by common letter(s) are not significantly $(\mathrm{p}<0.05)$ different as determined by Duncan's New Multiple Range Test (DMRT).

After 15 weeks, some of the plantlets when transferred to liquid 1 NAA mg/lt MS medium(3 weeks) showed better response in all the above parameters in comparison to solid 1 NAA mg/lt MS medium. The number of multiple shoots per plantlet was found to be more in liquid medium than solid medium(Table: 3).

Table 3: Comparison of different parameters of liquid and solid medium of the same concentration tried in MS medium of D. fimbriatum var. oculatum (5 months/ 20 weeks)

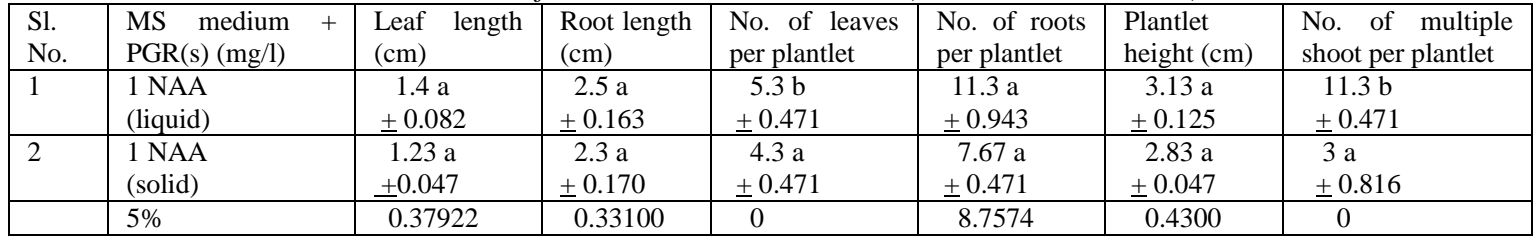

Means followed by common letter(s) are not significantly $(\mathrm{p}<0.05)$ different as determined by Duncan's New Multiple Range Test (DMRT). 
It was found that liquid MS medium leads to an increase in the total number of roots/plantlet. Liquid culture was better suited for root cultures (Street,1969). NAA enriched medium (MS) favoured multiple shoot bud formation (Vij and Kaur, 1998). The quantity and quality of roots and leaves, plantlet height and multiple shoot induction was found to be the best in full strength liquid MS medium (with 3\% sucrose) in comparison to other strengths $(1,2,1,4,1 / 8)$ of liquid MS medium (Table:4). The growth and development of Dendrobium fimbriatum var.oculatum was more vigorous and faster, roots developed at a faster rate and the medium devoid of any hormonal supplements was found to be the best as reported by Haque et.al(1994).Total number of multiple shoots per node is -36.9 shoots /nodal explant(average).

Table 4: Comparison of different parameters of liquid medium without PGR(s) for standaradisation further to potting medium in D. fimbriatum var. oculatum under in vitro conditions. (5 months / 20weeks)

\begin{tabular}{|c|c|c|c|c|c|c|c|}
\hline $\begin{array}{l}\text { S1. } \\
\text { No. }\end{array}$ & $\begin{array}{l}\text { MS liquid medium in } \\
\text { different strengths }(\mathrm{mg} / \mathrm{l})\end{array}$ & $\begin{array}{l}\text { Leaf length } \\
(\mathrm{cm})\end{array}$ & $\begin{array}{l}\text { Root length } \\
(\mathrm{cm})\end{array}$ & $\begin{array}{l}\text { No. of leaves } \\
\text { per plantlet }\end{array}$ & $\begin{array}{l}\text { No. of roots } \\
\text { per plantlet }\end{array}$ & $\begin{array}{l}\text { Plantlet } \\
\text { height }(\mathrm{cm})\end{array}$ & $\begin{array}{l}\text { No. of multiple } \\
\text { shoot per plantlet }\end{array}$ \\
\hline 1 & Full & $\begin{array}{r}1.53 \mathrm{~b} \\
+0.125\end{array}$ & $\begin{array}{r}2.63 \mathrm{a} \\
+0.170\end{array}$ & $\begin{array}{r}5.67 \mathrm{~b} \\
+0.471\end{array}$ & $\begin{array}{l}14.67 \mathrm{c} \\
+1.247\end{array}$ & $\begin{array}{r}3.37 \mathrm{a} \\
+0.125\end{array}$ & $\begin{array}{r}9.67 \mathrm{~d} \\
\pm 0.471\end{array}$ \\
\hline 2 & $1 / 2$ & $\begin{array}{l}1.40 \mathrm{ab} \\
+0.082\end{array}$ & $\begin{array}{r}2.57 \mathrm{a} \\
+0.047\end{array}$ & $\begin{array}{l}5 \mathrm{ab} \\
+0\end{array}$ & $\begin{array}{l}12 \mathrm{bc} \\
+1.632\end{array}$ & $\begin{array}{r}3.10 \mathrm{a} \\
+0.082\end{array}$ & $\begin{array}{r}4.67 \mathrm{c} \\
+0.471\end{array}$ \\
\hline 3 & $1 / 4$ & $\begin{array}{l}1.40 \mathrm{ab} \\
\pm 0.082\end{array}$ & $\begin{array}{r}2.47 \mathrm{a} \\
+0.094\end{array}$ & $\begin{array}{r}4.3 \mathrm{ab} \\
+0.471\end{array}$ & $\begin{array}{l}10 \mathrm{~b} \\
+1.414\end{array}$ & $\begin{array}{r}3.10 \mathrm{a} \\
+0.125\end{array}$ & $\begin{array}{l}1.67 \mathrm{~b} \\
\pm 0.471\end{array}$ \\
\hline 4 & $1 / 8$ & $\begin{array}{r}1.30 \mathrm{a} \\
+0.082 \\
\end{array}$ & $\begin{array}{c}2.53 \\
+0.125 \\
\end{array}$ & $\begin{array}{l}3.67 \mathrm{a} \\
+0.943 \\
\end{array}$ & $\begin{array}{r}4.3 \mathrm{a} \\
+0.471 \\
\end{array}$ & $\begin{array}{r}3.10 \mathrm{a} \\
+0.125 \\
\end{array}$ & $\begin{array}{r}1 \mathrm{a} \\
+0 \\
\end{array}$ \\
\hline & $5 \%$ & 0.1527 & 0.31270 & 1.4902 & 3.24960 & 0.29250 & 0.57741 \\
\hline
\end{tabular}

Means followed by common letter(s) are not significantly $(\mathrm{p}<0.05)$ different as determined by Duncan's New Multiple Range Test (DMRT).

\section{Acknowledgement}

Authors are pleased to offer there special thanks to then Head of the Department of Life Sciences, Dibrugarh University for providing necessary facilities to carry out the above work.

\section{References}

[1]. Arora,Y.K. and Mukherjee,A. (1983). Ornamental orchids of N.E.I ndia, Technical Bulletin No.5,ICAR Complex of NEH Region, Shillong, Meghalaya.

[2]. Adritti, J. Michaud, J.D. and Olivia, A.P. (1981). Seed germination of North American Orchids. Native California and related species of Calypso ,Epipactis ,Goodyera,Piperia,Platanthera, Bot. Gaz., 142: 442-453.

[3]. Chanda, K.L. (1992). The Orchids scenario, J. Orchid Soc. India. 6:1-4.

[4]. Chennaveeriah, M.S. and Patil, S.J. (1975). Morphogenesis in seed culture of Spathoglottis. Curr.Sci., 44:68.

[5]. Haque,M.I.,Roy, A.R., Sarkar,R.H. and Haque,M.M. (1994). Micropropagation of Cymbidium bicolor through in vitro culture. Plant Tissue Culture.( Bangladesh)., 4: 45-51.

[6]. Murashige,T., and Skoog F.(1962). A revised medium for rapid growth and bio assays with tobacco tissue cultures. Physiologia Plantarum, 15:473-497.

[7]. Quattocchu, U.,(2012). CRC World Dictionary of Medicinal and Poisonous PLants: Common names.1351-1352. https: // www. cre press.com>book

[8]. Rao A.N. and Avadhani, P.N. (1963). Some aspects of in vitro culture of Vanda seeds. In: Proc. $4^{\text {th }}$ World Conf. Singapore, pp. 194-202.

[9]. Satish, Kumar, C. and Maninlal, K.S.(1994). A catalogue of Indian Orchids. (Ed., Bishen Singh Mahendra Pal Singh). Dehra Dun., 63-87.

[10]. Street, H.E.(1969). Growth in organized and unorganized systems. Knowledge gained by culture of agar and tissue explants. In: Steward, F.C.(Ed.). Plant Physiology- A Treatise. pp. 3-224. Lond-New York: Academic Press.

[11]. Vij, S.P. and Kaur, S.(1998). Micropropagation of therapeutically important Orchids: Malaxis acuminata D.Don. Journal of Orchid Society of India., 12: 89-93. 